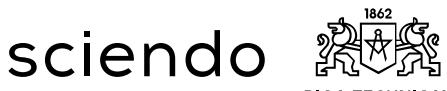 \\ RIGA TECHNICAL
}

ISSN: 2255-9671 (online)

2019, 7, 123-134

doi: 10.2478/bjreecm-2019-0008

https://content.sciendo.com

\section{INFRASTRUCTURE DEVELOPMENT AND PROPERTY SALES IN LOW INCOME RESIDENTIAL PROPERTIES IN BULAWAYO}

\author{
Chigwenya Average ${ }^{1}$, Desire Dube ${ }^{2}$ \\ ${ }^{1}$ Department of Landscape Architecture and Urban Design, \\ National University of Science and Technology, Bulawayo, Zimbabwe \\ ${ }^{2}$ John Pockock Real Estate, Bulawayo, Zimbabwe \\ Corresponding author's e-mail: chigwenyaaver@gmail.com
}

\begin{abstract}
There is a usual positive correlation between infrastructure development and property sales, because infrastructure development has positive externalities on property sales. However, in Bulawayo this correlation is not usually present in all aspects of properties transactions. The research seeks to find out the trends in infrastructure development and property sales in the city of Bulawayo. The research also aims to unearth some of the factors other than infrastructure development that determine property values in Bulawayo's lowdensity suburbs. The research took a mixed methods approach to data collection where both qualitative and quantitative methodologies were utilised. Questionnaires were administered to the people in low income areas of Pumula, Cowdrey Park and Emganwini. In depth interviews with key informants in the real estate sector were conducted to cross fertilise and enrich the inquiry. The research found out that in most cases there is a strong correlation between infrastructure development and property sales, but in some cases, this is not the case as some forces are put in play to distort the market play. The research also discovered that apart from infrastructure, property sales in Bulawayo's lowincome residential suburbs are also affected by income, supply of houses and demand for these houses. In Bulawayo, there are bottle-necks in the supply of houses and this has distorted the market because people are taking whatever there is on the market at any price. This has reduced the influence of infrastructure development on property sales.
\end{abstract}

Keywords: Infrastructure development, Property values, Property market, Valuation.

\section{INTRODUCTION}

Property values differ with the type of use, the kind of available infrastructure, the age of the buildings and the socio-economic environment that is prevailing in the area where the property is located. In all these factors, infrastructure plays a critical role in determining the property values. Without infrastructure land is just void and lacks value. According to Mills (1972), without sewerage, water, and electricity land is just a skeleton and is without value. Such properties fetch very low values in the market because they are usually regarded as unplanned and they also do not give people the desired intrinsic values. Properties that are endowed with good infrastructure provision have good accessibility and this has positive 
externalities in terms of boosting their values in the market. According to SaluKasoko et al. (2013), infrastructure is one of the key determinants of property values which lead to the appreciation of property values, and there is adverse depreciation of property values in the areas that do not have a good infrastructure. Hammer et al. (2000) argued that there is a positive correlation between infrastructure development and residential property values because the provision of good and sufficient infrastructure is the key to property values. Recently, Zimbabwean cities have been witnessing a rapid and uncontrolled urban development and this has created a very serious problem in the property market. This unprecedented move has created market distortions. This study tries to examine how infrastructure development has influenced property values in the city of Bulawayo. The study also examines the extent to which infrastructure development can produce positive externalities on the property market.

\section{RESEARCH METHODOLOGY}

The research used a multi-pronged approach to the inquiry, where mixed methods approach to the research was adopted. In the inquiry, both qualitative and quantitative methodologies were used. The questionnaire was the only qualitative method used. It was administered to 100 people in the low residential areas of Bulawayo. Interviews with the key informants in the real estate industry were conducted and these included the owners of estate agencies, developers and the government section of public works. In total 10 interviews were conducted with five estate agents, four property developers and one government department. Field observations also complimented the qualitative methods, where observations were done using transact walk in the low-density residential areas to assess the level of infrastructure development in various areas. Data from questionnaires was analysed using SPSS and this helped create tables and graphs. Qualitative data were analysed qualitatively using thematic areas.

\subsection{An Inventory of Infrastructure Facilities in Bulawayo's High Density Areas}

Infrastructural disparities are found in the high-density suburbs of Bulawayo. In some areas (Emganwini, Pumula and the other part of Cowdrey Park) there is good provision of infrastructure ranging from good tarred roads, provision of supporting institutions such as schools, churches and commercial services. These areas are also endowed with good water, sewerage and electricity supply. However, residents in these areas think that it will be good for them if this infrastructure is well maintained. Maintenance is one of the factors that is disadvantaging these areas because frequent sewer burst often put residents at risk of contracting water borne diseases. Table 1 shows infrastructural provisions that are commonly found in most of the high-density suburbs of Bulawayo and their conditions. Most areas of Bulawayo high density areas seem to have infrastructure that supports people's lives such as roads, water, sewerage, educational facilities and health facilities. However, in some areas such as Cowdrey Park such infrastructure is scantly provided and in some cases is not available. 
Table 1. General Conditions of Infrastructure in Most High Density Suburbs of Bulawayo (developed by the authors)

\begin{tabular}{|l|l|}
\hline Infrastructure & General Comment \\
\hline Tarred roads & Poorly maintained with pot holes \\
\hline Gravel roads & Eroded by water \\
\hline Electricity & Available, although load shedding \\
\hline Reticulated water & Available, although accesses on specific times \\
\hline Reticulated sewerage & $\begin{array}{l}\text { Available, although some are aged and there } \\
\text { are frequent bursts }\end{array}$ \\
\hline Primary and secondary schools & Available in the area within 3-5 km radius \\
\hline Clinics & $\begin{array}{l}\text { Available and at a good distance (within } \\
10 \text { km radius) }\end{array}$ \\
\hline Proper shopping facilities & $\begin{array}{l}\text { Available and at a good distance (within } 3 \mathrm{~km} \\
\text { radius) }\end{array}$ \\
\hline
\end{tabular}

However, there are other places such as the one that appeared during the Operation Restore Order in Murambasvina, which was a government programme meant to get rid of all informal settlement in all urban areas. The operation left more than 1.4 million people without houses (Potts, 2008). The government then went on to parcel out land to the affected people so that they could build their houses. These settlements are however poorly serviced as they lack essential services for human habitation. The areas do not have proper roads as the roads that are servicing these areas are just bushy roads that are not even gravelled to improve their quality (Fig. 1). Such roads can easily be washed away by rains. They also do not have water reticulation and most of the residents are getting their water from shallow wells and communal boreholes. Commercial areas are represented by tuck shops, which are small informal traders that service the areas. These structures are also not permanent, they are just makeshift structures made out of temporary materials such as wood and plastics (see picture below). If local residents want to access other commercial services, they have to walk more than five kilometres to the nearest supermarket, but some residents have to travel double that distance because they are located further away from these commercial services.

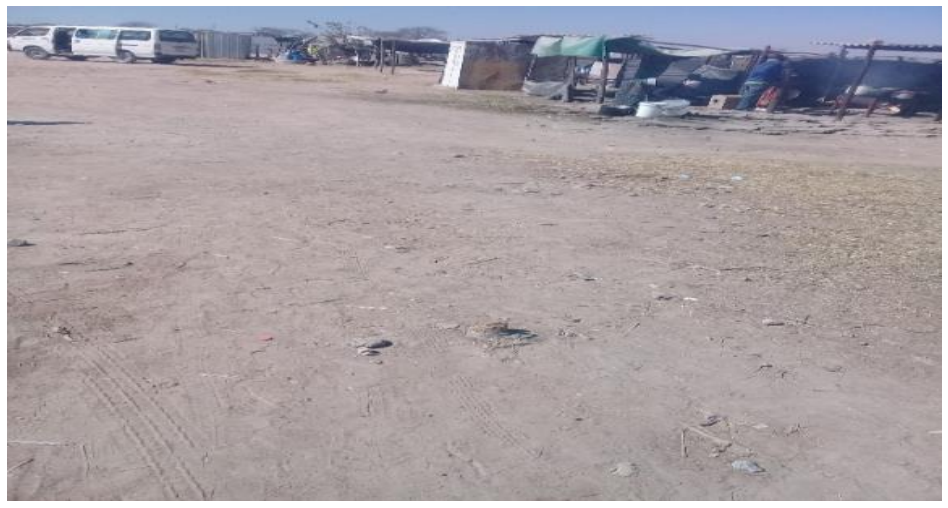

Fig. 1. The make-shift and run-down shopping facilities in Cowdrey Park. (Photo by D. Dube, co-author) 
The sewerage system does not exist in these areas as the houses are serviced by either eco-san toilets or Blair toilets. These sewerage systems are best for rural settlements, whereas water reticulated systems with flashing toilets are the right sewerage system for urban areas. However, the city authorities are planning to provide such important infrastructure. The Blair toilets are a potential threat to the health system of the city because in rainy seasons they flood, thereby posing a potential threat of ground water contamination. While the eco-san toilets are said to be an environmentally friendly sanitation system, there is need to monitor how they are treated so that they do not contaminate the environment. There are no schools in the area, so the people have to seek these services in the nearby locations. This forces school children to travel more than 10 kilometres to the nearest school. Table 2 shows the types of infrastructure and their conditions in the other side of Cowdrey Park and the general comments from the public. Most of the area is serviced by very poor infrastructure in the form of bushy roads, there is no electricity, no reticulated water and no educational facilities. Children walk more than $10 \mathrm{~km}$ to the nearest school.

Table 2. Type of Infrastructure in Cowdrey Park and the General Public Comments (developed by the authors)

\begin{tabular}{|l|l|}
\hline \multicolumn{1}{|c|}{ Infrastructure } & \multicolumn{1}{c|}{ General comments } \\
\hline Tarred roads & No tarred roads \\
\hline Gravel roads & Roads are not gravelled, just bush roads \\
\hline Electricity & No power, people use fire wood \\
\hline Reticulated water & Communal boreholes and shallow wells \\
\hline Reticulated sewerage & Eco-san toilets and Blair toilets \\
\hline Primary and secondary schools & No schools \\
\hline Clinics & No clinics \\
\hline Proper shopping facilities & Only tuck shops \\
\hline
\end{tabular}

The infrastructural deficiencies in Cowdrey Park section make the lives of local residents difficult as they walk long distances to the nearest convenience shops and in search of health facilities. The nature of the roads is such that most of the transport operators shun this place and those that service the areas are too expensive. The situation is very bad in the rain season because the transport operators stop servicing the area because of poor road infrastructure.

\subsection{Property Sales in High Density Residential Suburb of Bulawayo: A Comparative Study}

Property values reflect the interplay of various factors that include environment, the age and size of the buildings (Oloke et. al. 2013). In a perfectly functioning market, the value of the property is a function of the market interplay where potential buyers or tenants out-bid each other in order to obtain ownership or possession of the property. Infrastructure also plays a significant role in influencing property sales because infrastructure endowed areas are most preferred in the market and this raises the demand for them and subsequently their values. According to Frischmann (2005), user's willingness to pay higher prices for 
property, which is properly endowed with infrastructure, is high because they can derive more benefits from the infrastructure provided than those without. Thus, infrastructure development has positive externalities on property values. Infrastructure endowed areas such as Nkulumane, Pumula and Emganwini are the most preferred areas and people are prepared to pay high premiums to acquire properties in such areas. On the other hand, poorly endowed residential areas such as Cowdrey Park are less preferred hence are less on demand and this lowers their values. Figure 2 compares property sales in different high-density residential areas of Bulawayo. Nkulumane area is the one that is leading in property sales in the highdensity suburbs of Bulawayo because this area has good infrastructure that includes tarred roads in good condition, there is a very big shopping complex that services most of the suburbs in this southern region of the city. Other areas with fair infrastructural development are also doing fairly well in property sales and these areas include Emthunzini $(21 \%)$ and Lavenda (20\%). Although Pumula and Emganwini have aging infrastructure they also claim a significant share. However, poorly serviced areas of Cowdrey Park have a very low share in the property market (3\%) (See Figure 2). At the Nkulumane shopping complex there are several services that make it a very important node in terms of service provision in the areas. The residential area also houses district offices for the city of Bulawayo, thereby offering administrative function for the surrounding areas.

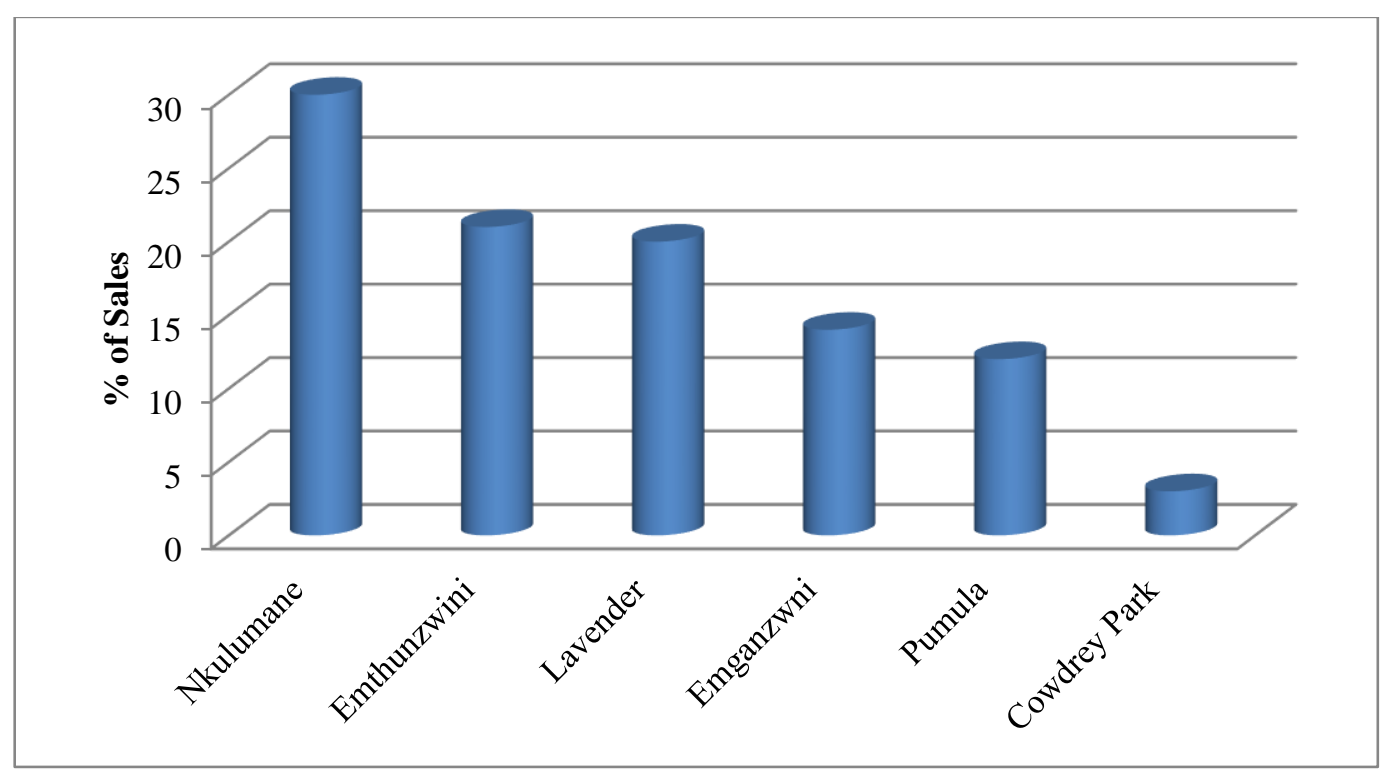

Fig. 2. Property sales in different residential areas of Bulawayo (developed by the authors).

Pumula and Emganwini recorded fairly low outputs in terms of property sales. This can be attributed to the nature of infrastructure in these areas. Pumula has ageing infrastructure but Emganwini is a fairly new suburb whose infrastructure is still under construction, so people prefer the areas with the properly developed infrastructure to those that have aged, nonexistent infrastructure and those with infrastructure that is still under construction. Cowdrey Park is the lowest ranked 
residential area in terms of provision of infrastructure. Residents in this area are complaining about frequent sewerage bursts and unattended gravel roads, which are characterised by severe erosion and pot holes. As mentioned above, Cowdrey Park is the residential area with very poor infrastructure. There are no good roads, power, sewerage and water reticulation systems are not installed. This area therefore is performing very poorly in terms of sales of property in the city. It only constitutes $(3 \%)$ of property sales in the high-density suburbs of Bulawayo.

Infrastructure resources are intermediate goods that create social value and are very important factors in the production systems of the city (Frischmann 2005, Famuyiwa and Otegbala 2012). Famuyiwa and Otegbala (2012) further argue that infrastructure provides multi-dimensional benefits that have a positive impact on property values. Its economic function is to lubricate the wheels of development and improve the wellbeing of humans. They maintain that housing cannot be viewed in isolation of the environment that surrounds it. It is actually the totality of environment and the quality of neighbourhood. Infrastructure therefore can be utilised productively downstream and such use is the primary source of social benefits. These social benefits are the most sought-after values when people are looking for properties. Therefore, according to Famuyiwa and Otegbala (2012), housing values tend to keep high in those locations that enjoy infrastructure development. According to Harvey (1993), people are prepared to pay high prices for properties that are properly serviced with good infrastructure. Infrastructure therefore has positive externalities on property values as its presence leads to appreciation of property values (Ajibola et. al. 2013). He further argues that good infrastructure gives efficiency in human activities and this leads to appreciation of property values. Infrastructure can play a very important role in the transformation of localities because infrastructure can be used as conduits for transforming resources into outputs, which will change the outlook of locations. As they change, they will be functioning more efficiently and enable more economic activities that will lead to growth and appreciation in property values. In a survey that was done among real estate experts in Bulawayo, the researchers discovered that the availability of infrastructure in an area influences decision on location of property acquisition.

The areas that are well endowed with infrastructure such as water, electricity, transport and sewerage are more valuable than those without. Transport infrastructure plays a very important role in improving the accessibility of the areas. As places are more accessible they attract more traffic, and as the traffic volumes increase, the rental of such location is likely to increase (Mikelbank 2004). The areas with good infrastructure are therefore on high demand as people compete to access such properties. Such competition pushes up the prices of such properties (Salu-Kasoko et al. 2013, Harvey 1993, Famuyiwa and Otegbala 2012). Mikelbank (2004) further argues that properties that are located near major highways are more valuable that those that are further away from the major arteries of the city.

Lack of infrastructure in Cowdrey Park is therefore the chief cause of the lowest property sales transactions in Bulawayo. These locations turn to lose many potential property buyers due to negative externalities that are associated with such properties. Lack of good shopping areas, poor roads, and lack of essential 
infrastructure for important services such as water, electricity and sewerage are the contributing factors for poor preferences for properties in Cowdrey Park. This research has discovered that most property buyers in the city of Bulawayo look for properties that can satisfy their needs and this is shown by the infrastructure that is associated with the residential areas. Responses obtained from $93.8 \%$ of real estate experts indicated that residential property buyers prioritise infrastructure together with the property selling price, when selecting a property in Bulawayo. According to Salu-Kasoko et al. (2013), real value in real estate depends on the available infrastructure, properties without infrastructure have therefore no value because they offer low or no utility to the potential buyers. Real estate has significance only as it satisfies human needs and desires. It can be argued that real estate can only satisfy human needs, if it is equipped with a reticulated sewerage and water supply systems, electricity, there is access to schools, health and shopping facilities and an accessible road network. Such properties are more attractive and demand for them is high, which promotes the bidding process that pushes prices up (Debrezion et al. 2007, Hammer et al. 2000, Hensher, 2012).

\subsection{Property Values in the High Density Residential Areas in Bulawayo}

Prices of the properties in the residential areas range from USD 12000 to USD 25000 with an average price of USD 18500 . This is the price of a four roomed house in the city's high-density suburbs. This price range is obtained in all high-density suburbs irrespective of the nature of infrastructure in the area. The price varies based on the general conditions of the property, where those properties that are better maintained will fetch higher prices than those that are poorly maintained. Even the properties in the poorly serviced areas of Cowdrey Park demonstrate the prices that match those of the better serviced areas of Emganwini, Pumula, and Nkulumane. In Nkulumane, there is the best infrastructure in the highdensity suburbs with good tarred roads and a well-developed shopping complex offering different commercial services such as banking, furniture, and grocery shops. A four roomed house in Cowdrey Park, which is poorly serviced, can be priced as high as USD 18 000, thus demonstrating the same sales value of a similar four roomed house in Pumula and Emganwini. These price similarities show that there are factors other than infrastructure that determine property prices. Factors of supply and demand are likely to produce such market trends, because the market will be so bottle-necked in terms of supply that people will be competing for the few available properties. According to Kiara (2014), in Namibia these factors of supply and demand are responsible for driving property prices upwards irrespective of the nature of the available infrastructure. The other factor is that the property owners take advantage of the shortages in the property market and therefore sell their properties at cost prices. They base their values on the cost of constructing the property. This however is contrary to the premises of the valuation theory, which states that property values are not the same as the cost of construction and also not the same as the price of the properties. Property value can be defined as the amount obtained in a sales transaction between a willing and able purchaser and a willing seller, for a particular property and at a specific time in an informed market. This implies that for any property sale, the property seller should first accept the value 
offered by the purchaser for a sales transaction to be concluded. By accepting a sales value offered by a purchaser, property sellers do not only set the sales value, but also validate property values. People in these areas therefore sell the properties in order to recover their costs of building. This again violates the valuation theory. Within the valuation theory, location plays a critical role in determining property values. Different locations have different characteristics and different values depending on the nature of the location. Most of the locations in the study areas are adequately endowed with good infrastructure in terms of good roads and other facilities. In Cowdrey Park, the area is scantly serviced and the roads are poorly developed. Most of the roads are bushy and transport operators shun the areas especially during rainy season, hence the area has poor connectivity. However, properties in these areas are fetching values that are close or similar to those areas which have good infrastructure development. According to Mikelbank (2004), locations that are properly serviced with roads have better connectivity and accessibility and this creates demand for properties in such areas. Hence, their values for both rental and capital uses are generally higher than those without. $\mathrm{He}$ further argues that such properties with high connectivity are the most preferred by households who are therefore prepared to pay high values for such properties. He further notes that properties that are further away from the main transport arteries tend to drop in their values by $2.3-3.8 \%$ as the distance increases from these transport infrastructures. A good infrastructure provision provides efficiency in human activities and positively influences the standard of living and economic growth. This therefore creates some positive externalities such as high standards of living and higher prospects for economic growth. Such positive externalities are highly sought after when one is looking for properties, hence they push the property values higher (Ajibola et.al. 2013). He further argues that good infrastructure provision has a transformative effect because it helps in transforming resources into outputs and such effects are highly sought after when people look for accommodation. Nubi (2002) also argued that infrastructure provision is a critical factor that weighs heavily on property values, because infrastructure provision allows cities to function properly by enabling economic growth and enhancing a high quality of life. He further argued that infrastructure is a critical component in real estate as it brings in human satisfaction. In his assessment, property has no value if it has no utility and utility can only be achieved if property has infrastructure. It can be argued that the condition of the house substantiates the rationale behind construction cost recovery in the event of a successful property sale. It is important to note that the demand for housing in the city of Bulawayo far outstrips the supply, so that when it comes to buying properties, the market is short supplied. Therefore, customers compete for the available stock of housing units. Bulawayo's housing waiting list is standing at 110000 according to the Government of Zimbabwe (2013) and this situation is observed against the background of poor supply of housing units for low income groups in the city. The city is only able to provide 3000 stands per year but it has been failing to provide such stands for the previous years because of economic difficulties that the country has been facing. The city is therefore not capable to provide serviced stands in the city, which again pushes the price of un-serviced stands by close to $33 \%$. For 
example, a 200 square metre stand was going on average for USD $17.00 / \mathrm{m}^{2}$ and it has now risen to USD $22.50 / \mathrm{m}^{2}$.

A comparison of the prices of stands in the areas with and without infrastructure shows that there is a marginal difference in their prices. For example, a serviced stand of $200 \mathrm{~m}^{2}$ in the high-density residential areas of Emganwini costs USD 4500 and an un-serviced stand in Cowdrey Park is marginally lower at USD 3500. Stands in Cowdrey Park are virtually undeveloped without any services such as water, roads, electricity and sewerage, but they are priced by a mere $25 \%$ less than the serviced stands. This shows that the impact of infrastructure on property values is minimal and therefore there should be other factors that significantly influence the prices of properties in these areas. In Cowdrey Park area, people have no access to reticulated water or sewerage; people are bringing water from shallow wells and communal taps. They are using Blair toilets and eco-san toilets but their prices are fair comparing with those in the areas in properly serviced areas. The area has no schools, clinics, shops and it is not serviced with good transport system but these deficiencies are not properly reflected in property prices. Property prices should reflect the services that are offered in the area and these services should drive the satisfaction that these properties give to their owners. Such satisfaction should make people ready to pay more for them. However, the situation in Bulawayo's highdensity suburbs in general and Cowdrey Park in particular does not follow this logic. People are ready to pay fairly high prices for poorly serviced areas and in some cases, people are living with virtually no services (Harvey 1993, Harvey and Jowsey, 2004, Aibangbee 1997). They complain that they are living a life that is divorced of urbanity because their communities resemble rural communities due to poor services that are offered in the area. Aibangbee (1997) further argued that a good infrastructure provision reduces the cost of doing business, which in turn increases the profitability levels of industrial activities in the area.

However, there is a marked difference that is shown in rental values between the areas with good infrastructure and those without. The rentals show marked differences, which indicates a marked influence of infrastructure on rental values. In the areas of Cowdrey Park, which is a poorly serviced area, the average rentals for a four roomed house are USD 78.00 per month. In Cowdrey Park some poor maintained properties are fetching as low as USD 40.00 per month, these are usually those properties that are still under construction. The property of the same size is offered for a rental USD 250.00 per month in the areas with good infrastructure such as Emganwini, Pumula and Nkulumane. Rentals have jumped more than three times in the properly serviced areas compared to those without. According to Salu-Kasoko et al. (2013), properties in the areas that are well endowed with good infrastructure, such as piped water and sewerage often fetch higher rentals compared to the areas without infrastructure because people are prepared to pay for services that are offered in the areas rather than staying in the areas that are severely constrained due to poor infrastructure provisions. Studies done by Acevedo et al. (2017) in Campo Grande, Brazil, showed that there are noticeable changes in housing prices when areas are provided with urban infrastructure, showing a positive correlation between infrastructure provision and property values. A regression analysis in this research also showed that there is a 
positive correlation between the infrastructure development and property values. A coefficient of 1.000 was found in such areas as Pumula South, Cowdrey Park and Emganwini in both property values and rental values. Pan et al. (2014:118) observed that the introduction of rail transit lines in the residential property in Shanghai resulted in positive externalities regarding the properties affected. According to Arnold et al. (2017), property values in South Africa are also affected by such factors as household incomes, which are also determined by affordability and accessibility of property finance. Also studies by Lombard et al. (2017) in Pretoria and Johannesburg showed that there is a positive correlation between property values and infrastructure development, because property values appreciated due to introduction of train stations in these cities. According to Rosato et al. (2017), mobility in residential areas is very important as it determines accessibility in the area and this makes the areas with such infrastructure good neighbourhood. However, Tsatsaronis and Zhu (2004) recognized other factors such as availability of land and construction cost as also having a significant influence on property values and rental values. Ajibola et al. (2012) also added that there is a significant statistical relationship between land use planning and property values.

Although there is a general perception that there are other factors such as income levels, fluctuation of foreign exchange rates and the general economic environment are at play in determining property values, the influence of infrastructure provision has proved to be a strong factor in determining the property and rental values. Foreign currency in Zimbabwe is mostly available on the parallel market and this has brought a lot of instability in the economy, which is also reflected in the property market. The majority $(75 \%)$ of the respondents, however, think that infrastructure provision has a strong bearing on property values. According to the studies done on infrastructure development in Nigeria by Bello and Olujimi (2009), properties that are properly endowed with good infrastructure have higher values because infrastructure contribute significantly to the development of property. They concluded that it is generally believed that provision of infrastructure in residential property would continue attracting prospective tenants. Augustine (2015) argued that Nigeria actually established a 0.905 positive correlation between property values and available infrastructure development.

\section{CONCLUSION}

Housing cannot be fully examined in isolation of the infrastructure that is associated with it. The provision of such infrastructure improves significantly the values of the property. In Bulawayo, the research has shown that there is a strong correlation between infrastructure provision and property values. It has been demonstrated that infrastructure provision has positive externalities on property. People in the city of Bulawayo have shown that they prefer properties that are located in infrastructures endowed areas, as these properties are highly sought after and they do not remain long on the market. However, infrastructure has shown to have very little effect on the values of properties in some high-density areas because there is a marginal difference in the values between properties in the infrastructure 
endowed areas and those in the areas without. It means that there are other factors that strongly contribute to that. This can be attributed to the supply system in the city. High demand for properties and the bottle-necked supply system are the pointers to that behaviour. Since people have no alternative in terms of other sources of supply, they have to rely on the few available properties. Since there are few properties in the market, the properties in less endowed infrastructure areas are valued almost the same as those in well infrastructure endowed areas and those with poor infrastructure provision. The city council is still battling to supply adequate housing because there are a lot people registered on the housing waiting list. Infrastructure development also showed that it is a critical component in setting rental values in the high-density areas of Bulawayo, because it has proved to be a strong factor in determining rental vales. In the areas that have no or scanty infrastructure the rental values have shown to be very low. In some cases, they constitute a half and in other cases a third of the values of those properties in the areas with good infrastructure provision.

\section{REFERENCES}

Acevedo P., Hobbs J. and Martinez S. (2017). The Impact of Upgrading Municipal Infrastructure on Property Prices: Evidence from Brazil, Inter-American Development Bank, Washington DC, United States of America. https://doi.org/10.18235/0000687

Aibangbee S. S. (1997). Functions of urban infrastructure in national development. 27 Annual Conference of Nigerian Institute of Estate Surveyors and Valuers, Premier Hotel, Ibadan, 1-6 April.

Ajibola M. O., Awodiran O. O., and Salu-Kosoko O. (2013). Effects of Infrastructure on property values in Unity Estate Lagos, International Journal of Economy, Management and Social Sciences, 5, 195-205.

Ajibola M. O., Oluwunmi A. O. and Eguh O. (2012). Examining the Factors Contributing to Affordable Housing in Kosofe Local Government Council Area, Lagos, Nigeria, Journal of Asian Business Strategy, 2(10).

Arnold K., le Roux A., and Hattingh M. (2017). Impact of Gautrain Stations on Property Prices and Sales Activity in the City of Johannesburg between 2006 and 2015, South African Journal of Geomatics, 6(2). https://doi.org/10.4314/sajg.v6i2.4

Augustine J. K. (2016). The Developments in Real Estate and Sustainable Urban Environment: A Case Study of Kilimani Area within Nairobi City County, Research Project of Master's Degree in Valuation and Property Management, School of The Built Environment, University of Nairobi.

Bello M. O. and Olujimi J. A. B. (2009). Effects of Infrastructural Facilities on the Rental Values of Residential Property, Journal of Social Sciences, 5(4), 332-341. https://doi.org/10.3844/jssp.2009.332.341

Debrezion G., Pels E., and Rietveld P. (2007). The Impact of railway stations on Residential and Commercial Property Values: A Meta-analysis, Journal of Real Estate, Finance and Economics, 35(2), 161-180. https://doi.org/10.1007/s11146-007-9032-z

Famuyiwa F., and Otegbulu A, (2002). Public water infrastructure in property prices: an environmental evaluation approach, Elixir Infrastructure Management, 51, 11034-11038.

Frischmann B. M. (2005). An Economic Theory of Infrastructure and Commons Management, Minnesota Law Review.

Government of Zimbabwe (2013). Regional Town and Country Planning Act (Chapter 29:12), Printflow (Private) Limited, Harare, Zimbabwe.

Harmmer L., Booth D., and Love H. E., (2000). Poverty and transport. A report prepared for World Bank in Collaboration with DFID, ODI, London. 
Harvey J., (1993). Urban Land economics. Macmillan, London.

Harvey J. and Jowsey E. (2004). Urban Land Economics, Sixth Edition. Palgrave, Red Globe Press: London, United Kingdom.

Hensher A. D., Li Z. and Mulley C. (2012). The Impact of High Speed Rail on Land and Property Values: A Review of Market Monitoring Evidence from Eight Countries, Road and Transport Research, 21(4), 3-14.

Lombard S., Behrens R., and Virully F. (2017). Value Creation Around Transport Infrastructure in South Africa: The Case of Gautrain, $36^{\text {th }}$ Southern African Transport Conference (SATC 2017), 10-13 July, Pretoria, South Africa.

Mikelbank B. A. (2004). Spatial analysis of the relationship between housing values and investments in transportation infrastructure, The Annals of Regional Science, 38(4), 705-726. https://doi.org/10.1007/s00168-003-0187-0

Nubi T. O. (2002). Procuring, Managing and Financing Urban Infrastructure. Towards Integrated Approach, Presented at a National Working on Land Management and Property tax Reform in Nigeria. Organized by Estate Management Department UNILAG, Akoka.

Oloke O. C., Simon R. F. and Adesulu A. F. (2013). An Examination of the Factors Affecting Residential Property Values in Magodo Neighbourhood, Lagos State, International Journal of Economy, Management and Social Sciences, 2(8).

Pan Q., Pan H., Zhang M., and Zhong B. (2014). Effects of Rail Transit on Residential Property Values: Comparison Study on the Rail Transit Lines in Houston, Texas and Shanghai, China, Transportation Research Record: Journal of the Transportation Research Board. https://doi.org/10.3141/2453-15

Potts D., (2008). The urban informal sector in Sub-Saharan Africa: from bad to good (and back again?), Development Southern Africa, 25(2), 151-167. https://doi.org/10.1080/03768350802090527

Rosato P., Breil M., Giupponi C., and Berto R. (2017). Assessing the Impact of Urban Improvements on Housing Values: A Hedonic Pricing and Multi-Attribute Analysis Model for the Historic Centre of Venice, Special Issue Real Estate Economics, Management and Investments, Buildings 2017, 7(4), 112. https://doi.org/10.3390/buildings7040112

Salu-Kasoko O, Ajibola M. O. and Awodiran O. Q. (2013). Effects of Infrastructure on Property Values in Unity Estate, Lagos, Nigeria, International Journal of Economy, Management and Social Sciences, 2(5).

Tsatsarinos K., and Zhu H., (2004). What drives housing prices dynamics: Cross-Country evidence, BIS, Quarterly, March 2004. Available from

http://www.hkimr.org/uploads/conference_detail/775/con_paper_0_211_zhu-haibin-paper.pdf

\section{AUTHORS' SHORT BIOGRAPHIES}

Chigwenya Average is a lecturer at Department of Landscape Architecture and Urban Design, National University of Science and Technology, Bulawayo, Zimbabwe. He has been researching on wide range of issues in the topics related to the built environment, including planning of the real estate and urban management.

Desire Dube is a principal valuer, John Pockock Real Estate, Bulawayo, Zimbabwe. 